\title{
Sætningsstruktur og strukturelle flertydigheder
}

\section{Sten Vikner}

\begin{abstract}
There is agreement across different approaches that although sentences consist of words, they are much more than strings of words: They also have structure. Section 1 shows how clause structure is analysed very differently across different approaches.

The rest of the paper addresses ambiguity: lexical ambiguity in section 2, morphological structural ambiguity in section 3, and syntactic structural ambiguity in section 4.

Subsections 4.1-4.2 analyse the ambiguity arising when a constituent, e.g. a PP, is interpretable either as the sister of one constituent or of another constituent. Subsection 4.3 argues that the ambiguous examples analysed in all of section 4 cannot be accounted for within approaches that do not recognise a constituent that contains a verb and its complement (i.e. a VP).
\end{abstract}

\section{Nøgleord}

strukturel flertydighed, leksikalsk flertydighed, sætningsstruktur, konstituenter, konstituenttests, generativ tilgang, funktionel tilgang, VP (verbalfrase)

\section{Indledning: sætningsstruktur}

Sætninger har intern struktur, hvilket vil sige at de ikke bare består af rækker af ord. En sætning (eller bisætning) som

$$
\text { (... at) de studerende snakkede om mit foredrag. }
$$

består selvfølgelig af de seks ord, men den indeholder også fem andre konstituenter (dvs. andre enheder). Disse andre konstituenter består alle af mere end et ord: 
- de studerende,

- mit foredrag,

- om mit foredrag, og

- snakkede om mit foredrag,

og så selvfølgelig hele sætningen,

- de studerende snakkede om mit foredrag.

Dette kan illustreres ved hjælp af kasser:

(2)

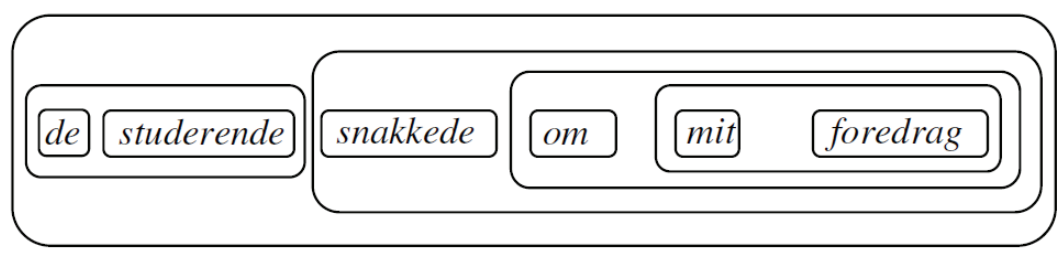

En variant af disse kasser er at bruge kantede parenteser, []:

$$
[[\text { de }][\text { studerende }]][[\text { snakkede }][[\mathrm{om}][[\text { mit }][\text { foredrag }]]]]]
$$

og endnu et alternativ er at illustrere sætningsstruktur ved hjælp af en træstruktur:

(4)

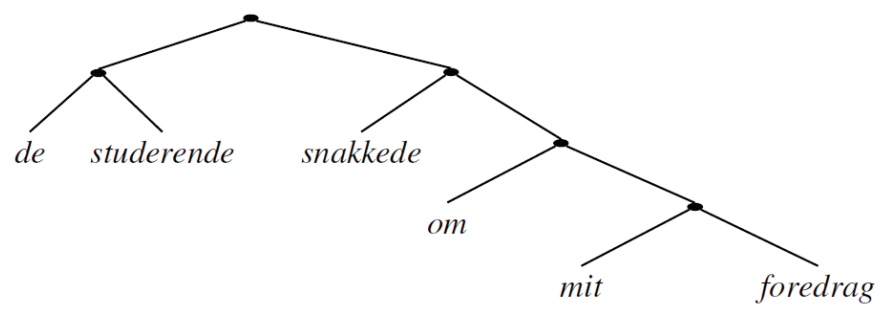

Jeg synes at en træstruktur som (4) er noget mere overskuelig end alternativerne i (2) og (3). Ikke desto mindre indeholder (2), (3) og (4) præcis den samme information, dvs. de er notationelle varianter af hinanden.

Både de strukturer jeg har vist indtil nu, i (2)-(4), og de strukturer jeg anvender i diskussionen nedenfor (i afsnit 4), er stærkt forenklede i forhold den generative analyse man oftest møder af dansk (fx Vikner \& Jørgensen 2017), svensk (fx Holmberg \& Plazack 1995), norsk (fx Åfarli \& Eide 2003) og islandsk (fx Thráinsson 2007). Før jeg vender tilbage til de forenklede 
analyser, vil jeg derfor i (5a) og (8b) kort vise hvordan en mere detaljeret generativ analyse ser ud og sammenligne den med to alternativer, nemlig to typer analyser der ofte anvendes af danske funktionelle lingvister. Disse sammenligninger skal udelukkende give et overblik over forskellene, og derfor henvises der til de citerede fremstillinger hvad detaljerne angår.

Den generative analyse af dansk i (5a) bliver her sammenholdt med Diderichsens $(1946,1964)$ to sætningsskemaer i $(5 b, c)$, som ligger til grund for de fleste danske lingvisters funktionelle analyser af danske sætninger:

b.

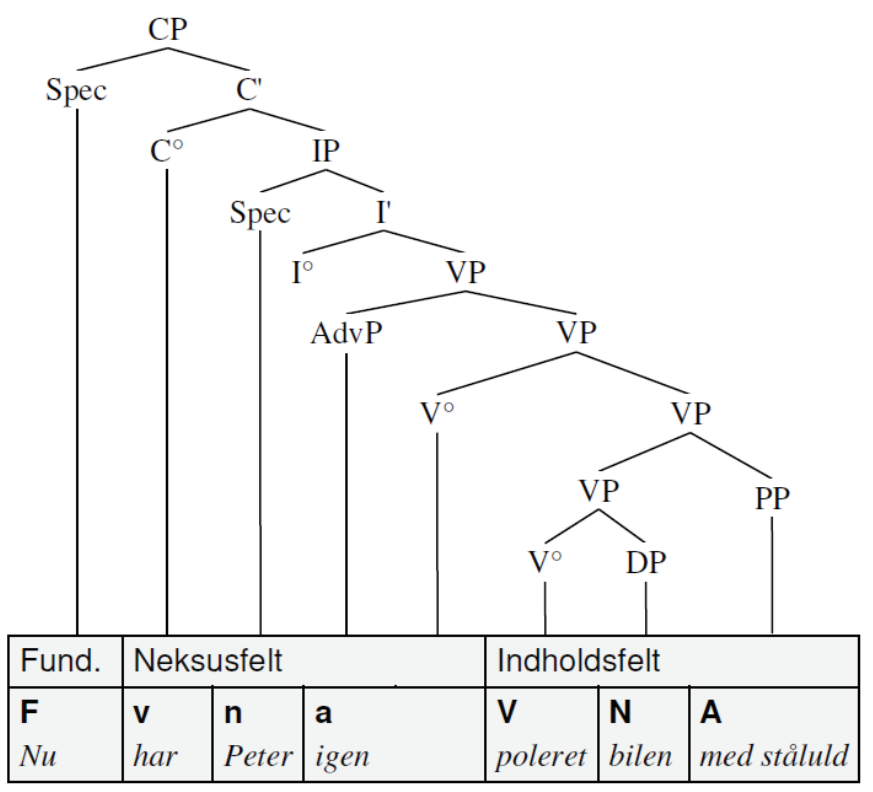

c.

\begin{tabular}{|l|l|l|l|l|l|l|l|}
\hline \multicolumn{2}{|l|}{ Konj. felt } & \multicolumn{3}{|l|}{ Neksusfelt } & \multicolumn{3}{l|}{ Indholdsfelt } \\
\hline$(\mathrm{F})$ & $\mathbf{k}$ & $\mathbf{n}$ & $\mathbf{a}$ & $\mathbf{v}$ & $\mathbf{V}$ & $\mathbf{N}$ & $\mathbf{A}$ \\
& om & Peter & igen & har & poleret & bilen & med ståluld \\
\hline
\end{tabular}

Der er to typer forskelle mellem de to analyser, (5a) vs. (5b,c). En er at de deler en sætning op i helt forskellige bestanddele ( $\mathrm{fx}$ IP vs. neksusfelt), og dette er helt klart en væsentlig forskel. Den anden forskel er hvordan de to forskellige opdelinger typisk illustrereres (dvs. træstruktur vs. feltstruktur), og dette er ikke en væsentlig forskel, men blot en notationsforskel. Træstrukturen i (5a) kan også illustreres som en feltstruktur, som i (6), og sætningsskemaet i (5b) kan også illustreres som en træstruktur, som i (7) uden at forskellene mellem analyserne går tabt: 
(6)

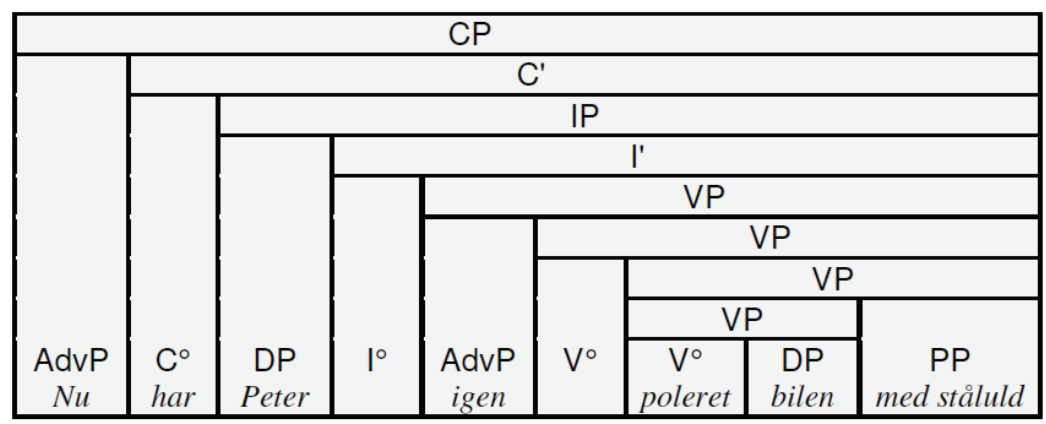

(5) $\mathrm{b}$

\begin{tabular}{|c|c|c|c|c|c|c|}
\hline Fund. & \multicolumn{3}{|c|}{ Neksusfelt } & \multicolumn{3}{|c|}{ Indholdsfelt } \\
\hline $\mathbf{F}$ & $\mathbf{v}$ & $\mathbf{n}$ & $\mathbf{a}$ & $\mathbf{V}$ & $\mathbf{N}$ & $\mathbf{A}$ \\
$N u$ & har & Peter & igen & poleret & bilen & med ståluld \\
\hline
\end{tabular}

(7)

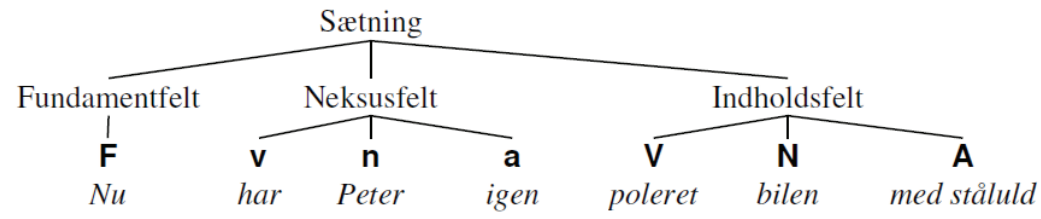

Det er faktisk meget muligt at det er lettere at se de væsentlige forskelle mellem den generative analyse og Diderichsens $(1946,1964)$ analyse hvis man kun sammenligner de to feltstrukturer (5b) og (6), eller hvis man kun sammenligner de to træstrukturer (5a) og (7).

Et eksempel på en tredje type analyse er træstrukturen i (8a), som anvendes i mange danske lingvisters funktionelle analyser af engelske sætninger, fx i Hjulmand \& Schwarz (2017) og også i Bache (2014) og i Bache \& Davidsen-Nielsen (1997). Den sammenholdes her med (8b), som er den generative analyse af engelske sætninger som den anvendes i fx Carnie (2013), Haegeman \& Guéron (1999), Johansson \& Manninen (2012), Poole (2011), Radford (2016) og Vikner (2015, 2016). 

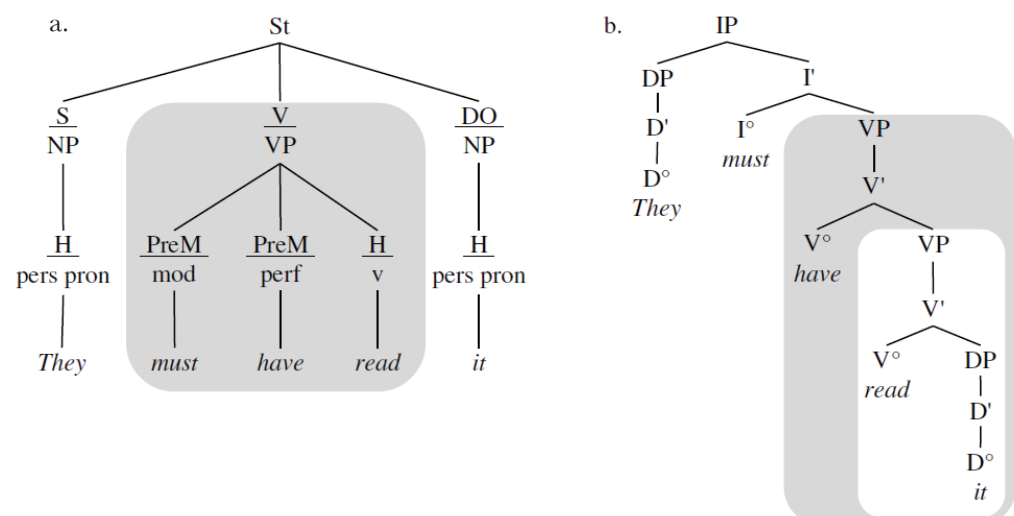

(De grå områder skal illustrere forskellene hvad angår verbalfrasens omfang og struktur.)

Udover at træstrukturerne i (5a), (6), (8b) vs. feltstrukturerne i (5b,c), (7) vs. træstrukturen i (8a) viser tre forskellige måder at analysere og illustrere sætningsstruktur, viser (5)-(8) også at notationsformen (kasser/felter vs. træer) ikke er nær så vigtig som selve konstituentinddelingen, dvs. hvilke ord der hører sammen i hvilke konstituenter.

Ikke desto mindre vil jeg her som sagt ikke gå i yderligere detaljer om forskellene mellem analyserne, men henvise til fx Bjerre, Engels, Jørgensen \& Vikner (2008) og Vikner \& Jørgensen (2017) vedr. (5a) vs. (5b,c) og til Vikner $(2015,2016)$ vedr. (8a) vs. (8b).

I stedet vil jeg gå videre med den generative analyse fra (4), (5a) og (8b) og vise hvordan denne kan tilbyde en interessant analyse af flertydigheder, og jeg vil først vende tilbage til de alternative analyser i forbindelse med diskussionen af (23) og (24) i afsnit 4.3 nedenfor.

\section{Leksikalske flertydigheder}

Først lidt om forskellen mellem leksikalsk flertydighed og strukturel flertydighed. Hvis en flertydig sætning er flertydig fordi et eller flere enkeltord har mere end én betydning, så er flertydigheden leksikalsk:

Her er der to flertydige udtryk (nemlig høj og spille kort), hvilket betyder at (9) har mindst fire forskellige fortolkninger, jf. (10a-d), som nok ikke alle er lige plausible: 

a. Kan man blive beruset af at spille kortspil?
b. Kan man blive lang af at spille kortspil?
c. Kan man blive beruset af at lade som om man ikke er ret stor?
d. Kan man blive lang af at lade som om man ikke er ret stor?

Idet høj også kan referere til høj lydstyrke, og spille kort kan også betyde at lade som om man er et landkort eller et spillekort, er der endda endnu flere læsninger end de fire i (10a-d).

\section{Strukturelle flertydigheder i morfologien}

Hvis et flertydigt udtryk er flertydigt ikke fordi et eller flere enkeltord har mere end en betydning, men udelukkende fordi det kan forstås som om det har enten én eller en anden struktur, så er flertydigheden strukturel. Det følgende engelske eksempel er specielt tydeligt:

(11) a.

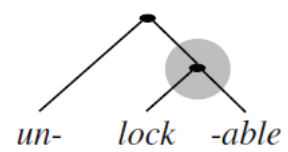

[un- [lock-able $]]$ "cannot be locked",

Da. ulåselig b.

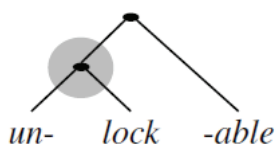

[[un-lock $]$-able $]$ "can be unlocked"

Da. oplåselig
STRUKTUREL

FLERTYDIGHED

(11a) og (11b) betyder to forskellige ting, men det er ikke fordi der er nogen af de enkelte konstituenter der har to betydninger. Flertydigheden ligger udelukkende i de to forskellige måder de tre elementer un-, lock og -able kan kombineres på.

De grå cirkler fremhæver de to konstituenter der kun findes i én af de to analyser. For yderligere detaljer af analysen i (11), se Vikner \& Vikner (2008).

\section{Strukturelle flertydigheder i syntaksen}

\subsection{Tilføjelse af en stedsangivelse}

Hvis man nu tilføjer en stedsangivelse (i form af en præpositionalfrase) som i Odense til sætningen i (1), făr man en strukturelt flertydig sætning:

$$
\text { (... at) de studerende snakkede om mit foredrag } i \text { Odense. }
$$


Denne sætning kan nemlig have to forskellige strukturer, se (13a,b), hvor de grå cirkler igen markerer de to konstituenter der kun findes i én af de to analyser.

I den ene læsning, (13a), er konstituenten $i$ Odense søster til konstituenten mit foredrag. Konstituenten $i$ Odense modificerer derfor konstituenten mit foredrag, dvs. den siger noget om hvor foredraget fandt sted.

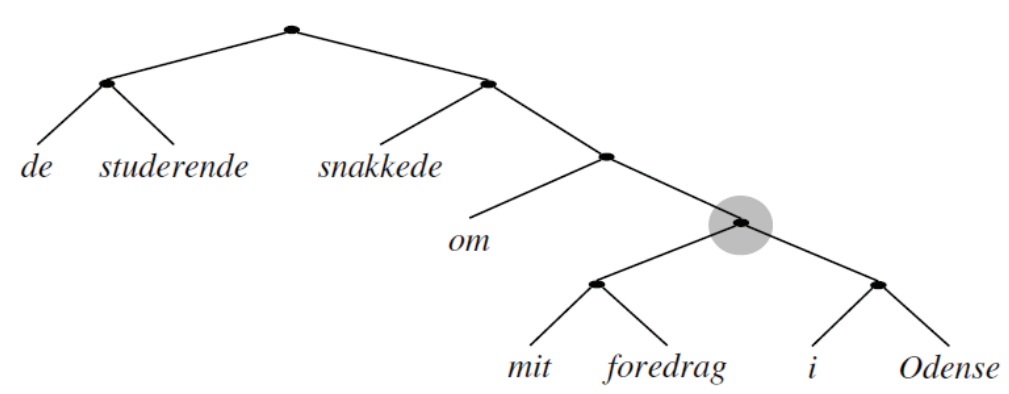

$(13 b)$

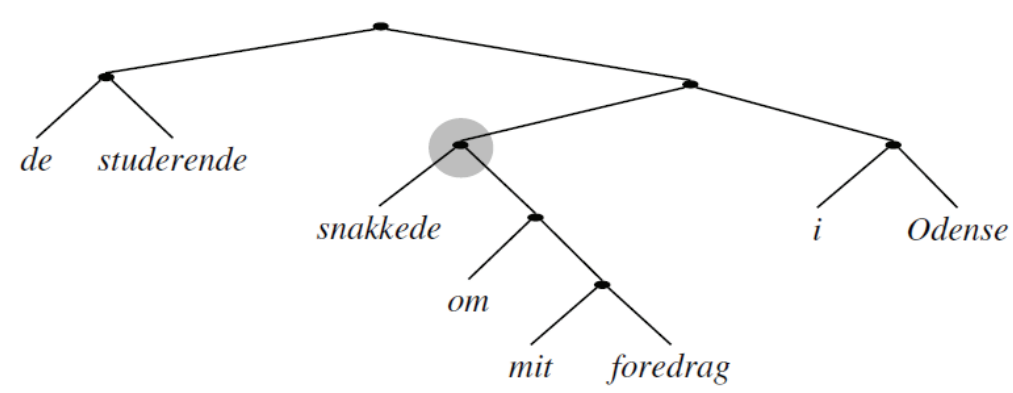

I den anden læsning, (13b), er konstituenten $i$ Odense søster til konstituenten snakkede om mit foredrag. Konstituenten $i$ Odense modificerer derfor konstituenten snakkede om mit foredrag, dvs. den siger noget om hvor snakken fandt sted.

I den læsning hvor konstituenten $i$ Odense kun er søster til (og dermed kun siger noget om) konstituenten mit foredrag, som i (13a), så udgør mit foredrag $i$ Odense som sagt én konstituent, og så kan man flytte rundt på denne konstituent:

(14) a. (... at) de studerende snakkede om mit foredrag $i$ Odense.

b. Det var mit foredrag $i$ Odense de studerende snakkede om

c. Det de studerende snakkede om var mit foredrag $i$ Odense. 
Sådanne konstituenttests anerkendes og anvendes i alle de tilgange der blev nævnt i indledningen: Diderichsen (1946: 163), Hjulmand \& Schwarz (2017: 53-56), Bache (2014: 15-18), Bache \& Davidsen-Nielsen (1997: 2022), Vikner (2015: 274, 2016: 444) og Vikner \& Jørgensen (2017: 149-154).

Tankegangen bag konstituenttests som (14) er følgende: Når fire ord som mit foredrag $i$ Odense kan flyttes rundt sammen, så er det fordi de udgør én konstituent. Idet de to tests i (14b,c) kun gælder for (13a) og ikke for (13b), forudsiges det også helt korrekt at hverken (14b) eller (14c) er flertydige: (14b) og (14c) kan kun betyde at mit foredrag fandt sted $i$ Odense, og de siger ikke noget om hvor de studerendes samtaler finder sted.

Hvis konstituenten $i$ Odense derimod er søster til (og dermed siger noget om) konstituenten snakkede om mit foredrag, (13b), så udgør snakkede om mit foredrag én konstituent, og så kan man substituere eller flytte rundt på denne konstituent:
a. (... at) de studerende snakkede om mit foredrag $i$ Odense.
b. Det de studerende gjorde $i$ Odense, var (at) snakke om mit foredrag.

Når fire ord som snakke om mit foredrag kan substitueres eller flyttes rundt sammen, så er det fordi de udgør én konstituent. Idet testen i (15b) kun gælder for (13b) og ikke for (13a), forudsiges det også helt korrekt at (15b) ikke er flertydig: (15b) kan kun betyde at de studerendes samtaler finder sted $i$ Odense, og den siger ikke noget om hvor mit foredrag fandt sted.

\subsection{Tilføjelse af to (inkompatible) stedsangivelser}

Det at en stedsangivelse som $i$ Odense enten kan være søster til (sige noget om) mit foredrag, (13a), eller være søster til (sige noget om) snakkede om mit foredrag, (13b), kan også forklare hvorfor resultatet ikke er flertydigt når vi hænger to forskellige (og inkompatible) stedsangivelser på den samme sætning:

$$
\text { (... at) de studerende snakkede om mit foredrag } i \text { Odense } i \text { Arhus. }
$$

I (16) er konstituenten $i$ Odense nødt til at være søster til (sige noget om) konstituenten mit foredrag, og konstituenten $i$ Arhus er nødvendigvis søster til (siger noget om) konstituenten snakkede om mit foredrag $i$ Odense: 


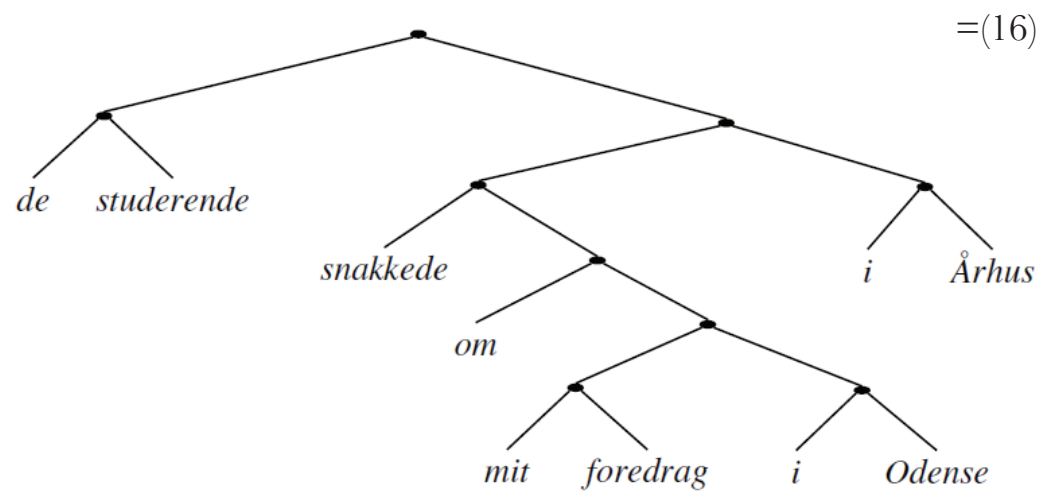

De andre to teoretisk mulige kombinationsmuligheder (nemlig at begge stedsangivelser siger noget om hvor foredraget fandt sted, eller at begge stedsangivelser siger noget om hvor der blev snakket) er nemlig udelukkede, bl.a. fordi $i$ Odense og $i$ Arhus ikke begge kan sige noget om det samme element. Det er derfor det er vigtigt at de to stedsangivelser er inkompatible, i modsætning til fx $i$ Odense på Fyn (der også kan læses som én konstituent).

Dette understøttes af resultaterne af de samme konstituenttests som blev anvendt i (14)-(15). Hvis analysen i (17) er på rette spor, så indeholder (16) både en konstituent der er mit foredrag $i$ Odense, (18a,b), og en der er snakkede om mit foredrag $i$ Odense, (19):
a. Det var mit foredrag $i$ Odense de studerende snakkede om $i$ Århus.
b. Det de studerende snakkede om $i$ Arhus, var mit foredrag $i$ Odense.

Endnu noget der følger hvis analysen i (17) er på rette spor, er at (16) så hverken indeholder en konstituent der er mit foredrag $i$ Odense $i$ Arhus, (20a,b), eller en konstituent der er snakkede om mit foredrag, (21). Dette kan således bruges til at forklare umuligheden af følgende eksempler:
a. *Det var mit foredrag $i$ Odense $i$ Arhus de studerende snakkede om
b. *Det de studerende snakkede om , var mit foredrag $i$ Odense $i$ Arhus. *Det de studerende gjorde $i$ Odense $i$ Arhus, var (at) snakke om mit foredrag.

Endelig kommer her to eksempler fra KorpusDK af samme slags som (16) og (17): 


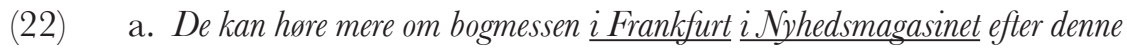
radioavis.

b. Kriminalpolitiet på Amager anholdt $i$ går eftermiddag en 35-årig libanesisk statsborger med asyl $\underline{i}$ Sverige, $i$ Kobenhavns lufthavn $i$ Kastrup.

Flere eksempler fra aviser og bøger findes i afsnit 4.4 nedenfor.

\subsection{Analysen af sådanne flertydigheder $i$ andre tilgange}

For at vise lidt om forskellene på de forskellige tilgange vil jeg diskutere en lidt mere kompliceret version af (16) og (17):

$$
\begin{aligned}
& \text { (... fordi) de studerende gerne ville have } \\
& {[\text { diskuteret [mit foredrag } i \text { Odense]] i Arhus]. }}
\end{aligned}
$$

Nøjagtig som i (17) ovenfor er $i$ Odense her i (23) nødt til at være søster til (sige noget om) mit foredrag, og $i$ Arhus er nødvendigvis søster til (siger noget om) diskuteret mit foredrag $i$ Odense:

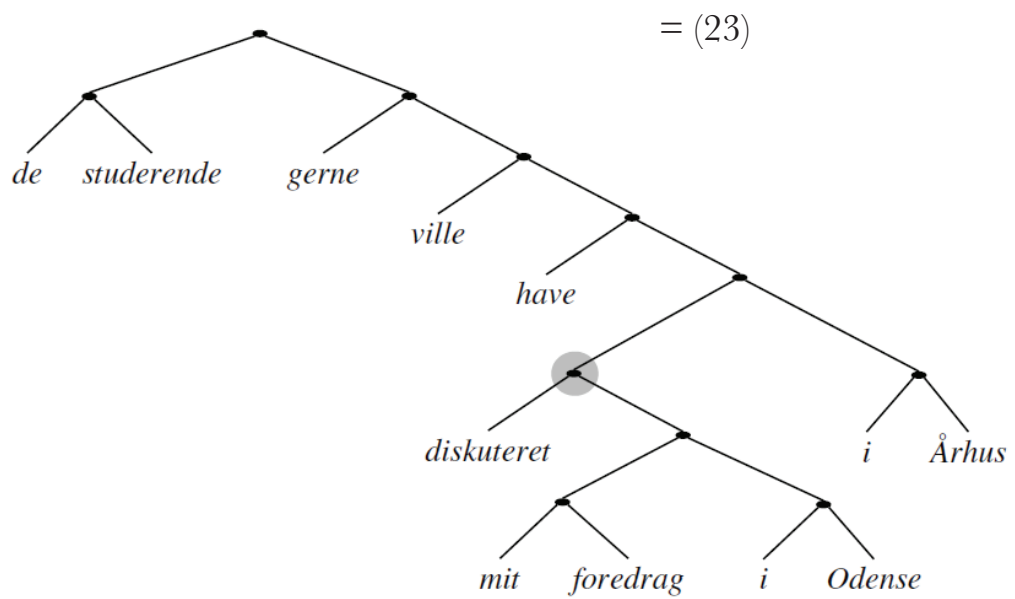

De konstituenttests som blev anvendt i (14)-(15) og i (18)-(21), gælder stadigvæk, men fordi der er mere struktur i (24) end i (13) og (17), forudsiger analysen i (24) også at (23) indeholder en konstituent der er diskuteret mit foredrag $i$ Odense (markeret med en grå cirkel i (24)), hvilket understøttes af følgende: 


\section{Det de studerende gerne ville have (gjort) iArhus var (at) diskutere mit foredrag i Odense.}

(24) forudsiger endvidere at (23) ikke indeholder en konstituent diskuteret mit foredrag, hvilket så forudsiger umuligheden af følgende eksempler:

\section{* Det de studerende gerne ville have (gjort) $i$ Odense i Arhus var (at) diskutere mit foredrag.}

Den konstituent som (25) påviser, nemlig diskuteret mit foredrag $i$ Odense, er en konstituent i den generative analyse jeg foreslår i (24) - nemlig en VP. Den udgør imidlertid ikke en konstituent i en analyse som Diderichsen (1946, 1964) fordi diskutere i en sådan analyse udgør en konstituent, V, sammen med have (se fx Vikner \& Jørgensen 2017 for flere detaljer). Dermed er det svært at se hvordan de flertydigheder jeg har diskuteret og analyseret ovenfor, kan forklares i en analyse som Diderichsen (1946, 1964).

Min VP, diskuteret mit foredrag $i$ Odense, udgør heller ikke en konstituent i analyser som Hjulmand \& Schwarz (2017) eller Bache (2014)1 , fordi diskutere i en sådan analyse udgør en konstituent (kaldet VP eller verb group) sammen med ville have (se fx Vikner 2015, 2016 for flere detaljer). Dermed er det svært at se hvordan de flertydigheder jeg har diskuteret og analyseret ovenfor, kan forklares i analyser som Hjulmand \& Schwarz (2017) eller Bache (2014).

\subsection{Flere eksempler på strukturelle flertydigheder}

Ved hjælp af analyser som dem foreslået ovenfor kan man således gøre rede for et stort antal af flertydigheder på engelsk og på dansk (og også på mange andre sprog).

I nedenstående eksempler er den konstituent der modificerer, understreget, og den konstituent der bliver modificeret, er både understreget og skrevet med fed skrift. Det er altså også her et spørgsmål om den konstituent der modificerer (fx by the Groveton police) enten skal fortolkes som søster til en større konstituent (fx reported stolen) i de tilsigtede læsninger, illustreret i aeksemplerne, eller den skal fortolkes som søster til en mindre konstituent (fx stolen) i de utilsigtede læsninger, illustreret i b-eksemplerne:

1 Idet Hjulmand \& Schwarz (2017) og Bache (2014) begge - som tidligere anført - er analyser af engelsk og ikke af dansk, er det værd at understrege at forholdene i engelsk er helt parallelle til forholdene i dansk hvad angår de data der diskuteres i afsnit 4.1, $4.2 \operatorname{og} 4.3$, jf. også de engelske data i afsnit 4.4 . 
(27) a. Two cars were reported stolen by the Groveton police yesterday.

b. Two cars were reported stolen by the Groveton police yesterday.

(citeret i Pinker 1994:102)

(28) Yoko Ono will ...

a. ...talk about her husband John Lennon who reas killed in an interview with Barbara Walters.

b. ... talk about her husband John Lennon who was killed in an interview with Barbara Walters.

(fra en programoversigt, citeret i Pinker 1994:102)

(29) a. I remember meeting a mother of a child who was abducted by the North Koreans right here in the Oval Office.

b. I remember meeting a mother of a child who was abducted by the

North Koreans right here in the Oval Office.

(George W. Bush, 26.06.2008, https://

georgewbush-whitehouse.archives.gov/news/

releases/2008/06/20080626-9.html)

Der blev også anført mange flertydigheder af samme type i dagbladet Politikens rubrik Oh Danmark (som selv tilføjede overskrifter der gjorde opmærksom på de utilsigtede læsninger, dvs. de læsninger der er illustreret i b-eksemplerne):

(30) NÅ SÅ DET VAR PERSONALET!

a. En Rembrandt og en Bellini til en samlet vurderingsverdi på et par hundrede millioner kroner blev stjålet ved hojlys dag af to yngre maend fra Nivaagaards Malerisamling.

b. En Rembrandt og en Bellini til en samlet vurderingsvardi på et par hundrede millioner kroner blev stjålet ved hojlys dag af to yngre maend fra Nivaagaards Malerisamling.

(Politiken) Politiken, Oh Danmark, 10.10.1999

(31) KENDSKAB TIL FORD T EN FORDEL

a. En dame til at komme sammen med og som kan kore bil på 60 - 70 år onskes af aldre enkemand.

b. En dame til at komme sammen med og som kan kore bil på 60 - 70 år onskes af eldre enkemand.

(Annonce i Kristeligt Dagblad) Politiken, Oh Danmark, 28.07.1996 
(32) HER TA'R MAN DET MED RO

a. Mindre dynamisk advokatkontor søger en HH'er med henblik på elevansattelse.

b. Mindre dynamisk advokatkontor søger en HH'er med henblik på elevansattelse.

(Annonce i Farum Avis) Politiken, Oh Danmark, 09.07.1995 KU' HUN IKKE NØJES MED ET PAR SøLVSKEER?

a. Uskyldig. Tjenestepigen Alma Bondesen, der blev beskyldt for tyveri af sit herskab.

b. Uskyldig. Tjenestepigen Alma Bondesen, der blev beskyldt for tyveri af sit herskab.

(Billedtekst i Politiken) Politiken, Oh Danmark, 26.08.2001

\section{SPEGIALBUTIK FOR BARNLØSE}

a. Rosengårdscentrets rabatbilletter til born, som vi salger ved sarlige lejligheder, er gået hen og blevet uhyre populare.

b. Rosengårdscentrets rabatbilletter til born, som vi salger ved sarlige lejligheder, er gået hen og blevet uhyre populare.

(Annonce i Ugeavisen Fyn) Politiken, Oh Danmark, 01.03.1998

\section{Konklusion}

Denne artikel $^{2}$ har forsøgt at vise hvordan man ved hjælp af sætningsstrukturanalysen kan redegøre for strukturelle flertydigheder.

I afsnit 1 anskueliggjorde jeg at sætninger har struktur, hvordan en sådan struktur kan illustreres inden for den generative lingvistik, og også inden for andre (danske) tilgange til henholdsvis dansk sætningsstruktur og engelsk sætningsstruktur. Jeg kom også lidt ind på hvad der er væsentlige forskelle mellem tilgangene, og hvad der derimod kun er notationsforskelle.

2 Tak til Ken Ramshøj Christensen, Katrine Rosendal Ehlers, Henrik Jørgensen, Anne Mette Nyvad, Carl Vikner og Johanna Wood, til en anonym reviewer og til mine medredaktører af dette nummer af $\mathcal{N y}$ forskning i grammatik, til publikum ved to foredrag hos Danske Sprogseminarer i København og i Århus, begge i september 2017, til publikum ved Grammatiknetværkets møde i Odense og ved Lingvistisk Weekendarrangement på Djursland, begge i oktober 2018, og ikke mindst til de studerende i mine kurser om dansk, engelsk og komparativ syntaks. Denne forskning begyndte som en del af to forskningsprojekter ved Aarhus Universitet, finansieret af Forskningsrådet for Kultur og Kommunikation: Objektspositioner - komparativ syntaks $i$ et tvarteoretisk perspektiv og Ligheder og forskelle mellem satninger og nominalgrupper - sammenlignende syntaks på tvars af teoretiske tilgange. 
Resten af artiklen handlede om flertydigheder: leksikalske flertydigheder i afsnit 2, morfologiske strukturelle flertydigheder i afsnit 3 og syntaktiske strukturelle flertydigheder i afsnit 4 .

I underafsnit 4.1 og 4.2 gik jeg nærmere ind på den type flertydighed der opstår når en konstituent, fx en stedsangivelse (i form af en præpositionalfrase), kan tolkes enten som søster til én konstituent eller som søster til en anden konstituent. I underafsnit $4.3 \mathrm{kom}$ jeg ind på hvorvidt sådanne analyser var mulige i de forskellige lingvistiske tilgange, og jeg argumenterede for at det var svært at se hvordan de flertydigheder der blev analyseret i 4.1-4.3 kunne få en tilfredsstillende analyse i tilgange der ikke antager konstituenter der består af et verbum og dets komplement (som fx Diderichsen 1946, 1964, Hjulmand \& Schwarz 2017 og Bache 2014).

\section{Om forfatteren}

Sten Vikner, professor i engelsk lingvistik, dr. phil. habil., Institut for Kommunikation og Kultur, Aarhus Universitet.

\section{Litteratur}

Bache, C. (2014). English Sentence Analysis. Odense: Syddansk Universitetsforlag.

Bache, C. \& Davidsen-Nielsen, N. (1997): Mastering English: An advanced grammar for non-native and native speakers. Berlin: Mouton de Gruyter.

Bjerre, T., Engels, E., Jørgensen, H. \& Vikner, S. (2008): Points of convergence between functional and formal approaches to syntactic analysis, Working Papers in Scandinavian Syntax 82, 131-166. <wrerc.hum.au.dk/engelsk/ engsu/papers/bjerO8a.pdf> (lokaliseret 30.03.2019)

Carnie, A. (2013). Syntax - A Generative Introduction. 3. udg. Chichester: Wiley-Blackwell

Diderichsen, P. (1946). Elementer Dansk Grammatik (3. udg. 1962, genoptrykt 1984). København: Gyldendal.

Diderichsen, P. (1964): Sætningsleddene og deres stilling - tredive år efter.

I: Danica, Studier i dansk sprog til Aage Hansen 3. september 1964. Genoptrykt i: Diderichsen, P. (1966): Helhed og Struktur. København: G.E.C. Gads Forlag, 364-379.

Haegeman, L. \& Guéron, J. (1999): English Grammar - A Generative Perspective. Oxford: Blackwell. 
Hjulmand, L. \& Schwarz, H. (2017): A concise contrastive grammar of English for Danish students (5. udg.). Frederiksberg: Samfundslitteratur.

Holmberg, A., \& Platzack, C. (1995): The role of inflection in Scandinavian syntax. New York: Oxford University Press.

Johansson, M. \& Manninen, S. (2012): English Linguistics - Introduction to Morphology, Syntax and Semantics. Lund: Studentlitteratur.

Mikkelsen, K. (1911): Dansk Ordföjningslere. København: Lehmann \& Stage. Genoptrykt 1975, København: Hans Reitzel.

Pinker, S. (1994): The Language Instinct - How the Mind Creates Language. New York: William Morrow.

Poole, G. (2011): Syntactic theory. Basingstoke: Palgrave Macmillan.

Radford, A. (2016): Analysing English Sentences (2. udg.). Cambridge: Cambridge University Press.

Thráinsson, H. (2007): The syntax of Icelandic. Cambridge: Cambridge University Press.

Vikner, C. \& Vikner, S. (2008): Hierarchical Morphological Structure and Ambiguity. I: L'énonciation Dans Tous Ses États - Mélanges Offerts à Henning Nolke, Merete Anderssen, Maj-Britt Mosegaard Hansen, \& Coco Norén (red.). Bern: Peter Lang, 541-60. <wwrw.hum.au.dk/engelsk/engsv/papers/ vikn08b.pdf> (lokaliseret 30.03.2019)

Vikner, S. (2015): Den engelske verbalfrases omfang og struktur. $\mathcal{N y}$ Forskning i Grammatik 22, 271-89. <https://doi.org/10.7146/nfg.v23i22.23497>

Vikner, S. (2016). English VPs and why they contain more than just verbs. I: Let us have articles betwixt us - Papers in Historical and Comparative Linguistics in Honour of Johanna L. Wood. Vikner, S., Jørgensen, H. \& Gelderen, E. van (red.). Aarhus: Engelsk Afd., Aarhus Universitet, 439-464.<https:// doi.org/10.7146/aul.119.107>

Vikner, S. \& Jørgensen, H. (2017): En formel vs. en funktionel tilgang til dansk sætningsstruktur. Nydanske Sprogstudier - NyS 52-53, 135-68. <https://doi.org/10.7146/nys.v1i52-53.24954>

Åfarli, T. A. \& Eide, K. M. (2003). Norsk generativ syntaks. Oslo: Novus. 